\title{
UPAH MINIMUM DALAM PERATURAN MENTERI TENAGA KERJA DAN TRANSMIGRASI NOMOR 7 TAHUN 2013 DITINJAU DARI PERSPEKTIF EKONOMI ISLAM
}

\author{
Ayu Yuningsih \\ Universitas Islam Indonesia, Yogyakarta \\ Emai: ayuyuningsih92@gmail.com
}

\begin{abstract}
Today the problems of labor and wages have been unsolved problems. The root of the problems that occur in workers or workers still lies in the issues of relations and agreements between employers and governments that ultimately impact on the workers. The Government has arranged a solution to solve the problem of injustice towards the labor of one of them through the determination of Minimum Wages as regulated in the Regulation of Minister of Manpower and Transmigration No. 7 of 2013, but the determination of Minimum Wage for workers is considered not to provide justice for laborers because the value of wages earned is comparable with the large role of labor services in realizing the business results of the company concerned. This paper aims to find out how the Islamic view of Minimum Wage is applied in Indonesia and find out whether the Minimum Wage determination has fulfilled the principles of Maslahah and Adl which are at the core of Islamic teachings.
\end{abstract}

Keywords: Labor, Minimum Wage, Islam

Abstrak: Dewasa ini permasalahan buruh dan upah menjadi masalah yag belum terpecahkan. Akar permasalahan yang terjadi pada buruh atau para pekerja masih terletak pada persoalan-persoalan hubungan dan kesepakatan antara pengusaha dan pemerintah yang akhirnya berimbas pada kaum pekerja. Pemerintah sudah mengatur solusi untuk memecahkan permasalahan ketidak adilan terhadap buruh salah satunya melalui penetapan Upah Minimum yang diatur dalam Peraturan Menteri Tenaga Kerja dan Transmigrasi Nomor 7 Tahun 2013, namun penetapan Upah Minimum bagi buruh dipandang belum memberikan keadilan bagi buruh karena seharusnya nilai upah yang diterima sebanding dengan besarnya peran jasa buruh dalam mewujudkan hasil usaha dari perusahaan yang bersangkutan. Paper ini bertujan untuk mengetahui bagaimana pandangan Islam mengenai Upah Minimum yang diterapkan di Indonesia dan mengetahui apakah penetapan Upah Minimum sudah memenuhi prinsip Maslahah dan Adl yang menjadi inti dari ajaran Islam.

Kata Kunci:Buruh, Upah Minimum, Islam

\section{A. PENDAHULUAN}

Dalam situasi perburuhan yang sifat dan dinamikanya semakin kompleks, upah masih tetap menjadi persoalan utama di negara berkembang seperti Indonesia. Keadaan pasar kerja yang dualistik dengan kelebihan penawaran tenaga kerja dan mutu angkatan kerja yang rendah di satu sisi menyebabkan upah menjadi issu utama dalam bidang ketenagakerjaan.

Kebijakan pengupahan yang ada masih bertumpu pada upah minimum yang berlandaskan pada kebutuhan hidup layak buruh/pekerja lajang dengan masa kerja di bawah satu tahun. Belum mencakup mereka yang bekerja di atas satu tahun dan berkeluarga. Perundingan kolektif sebagai alat perjuangan Serikat buruh/serikat pekerja untuk meningkatkan upah dan kesejahteraan buruh, perannya masih sangat terbatas, bahkan cenderung menurun kuantitas dan kualitasnya. Di sisi lain penerapan struktur skala upah masih sangat minim dan belum besifat wajib. Sehingga praktis upah minimum menjadi uapah efektif yang berlaku pada pasar kerja formal terutama sekali di sektor industri padat karya.

Upah merupakan komponen terbesar dari pendapatan seseorang sehingga tingkat 
\begin{tabular}{r|l} 
Ayu Yuningsih & 278
\end{tabular}

upah merupakan salah satu indikator yang mencerminkan kesejahteraan masyarakat dari suatu negara. Permasalah upah dewasa ini masih menjadi perhatian yang serius diantara banyak pihak seperti pekerja sebagai penerima upah, penusaha sebagai pihak pembayar upah, dan pemerintah sebagai regulator.

Untuk menjaga dan melindungi kaum buruh pemerintah melalui Kementerian Tenaga Kerja dan Transmigrasi membuat regulasi tentang upah dan buruh yang tertuang dalam Permen no 7 tahun 2013 tentang upah minimum. Dalam peraturan tersebut tertulis jelas bagaimana peran, hak dan kewajiban buruh dan mekanisme penetapan upah bagi kaum buruh, akan tetapi masih banyak kaum buruh yang merasa belum mendapat keadilan dalam pemenuhan hak-haknya sebagai buruh. Setiap peringatan hari buruh melalui serikat buruh, para buruh selalu mengeluhkan belum sesuainya upah yang diberikan dengan beban kerja dan kebutuhan hidup layak mereka.

Pendistribusian kekayaan merupakan salah satu unsur penting dalam kesejahteraan, dan Islam sangat memperhatikan hal tersebut. Inti ajaran Islam di bidang ekonomi adalah "Maslahah dan adl". Maslahah terkait dengan nilai absolut keberadaan barang, jasa, atau action (termasuk kebijakan ekonomi) dimana kesemuanya harus memenuhi kriteria-kriteria yang mengarah pada perwujudan syariah (maqashid al-syariah) yaitu perlindungan agama, jiwa akal, harta dan keturunan. Manusia tidak berhak atas bagian yang tidak diberikan Tuhan kepadanya, Tuhan memberikan pada setiap orang haknya oleh karena itu jangan menggangu apa yang dimiliki orang lain. Sementara adl terkait dengan interaksi relatif antara satu hal dengan hal lain, individu yang satu dengan individu yang lain, atau masyarakat tertentu dengan masyarakat yang lain. ${ }^{1}$

Setelah tenaga kerja atau buruh memberikan tenaga secara maksimal dalam proses memproduksi barang dan jasa yang diminta oleh majikan atau industri, maka hak tenaga kerja adalah mendapatkan upah untuk mewujudkan kesejahteraan hidup dirinya bersama keluarga, dalam kenyataan yang berlaku di negara kita upah yang diberikan secara umum atau kebanyakan upah yang diterima adalah "Upah minimum". Berdasarkan latarbelakang tersebut, maka dapat dirumuskan masalah sebagai berikut, Bagaimana pandangan Islam mengenai Upah minimum Regional. Apakah Upah Minimum Regional sudah memenuhi

\footnotetext{
${ }^{1}$ Susanto, Praktek Ekonomi Islam di Indonesia dan Implikasinya Terhadap Perekonomian. Jurnal Ekonomi Syariah Muamalah , 5, 2008.
} 
prinsip Maslahah dan Adl yang menjadi inti dari ajaran Islam?

Paper ini bertujan untuk mengetahui bagaimana pandangan Islam mengenai Upah Minimum yang diterapkan di Indonesia dan mengetahui apakah Upah Minimum sudah memenuhi prinsip Maslahah dan $A d l$ yang menjadi inti dari ajaran Islam.

Agar pembahasan paper lebih terarah, maka penulis membatasi pembahasan paper ini pada Upah Minimum Regional yang diatur dalam Permen Tenaga Kerja dan Transmigrasi nomor 7 tahun 2013 tentang upah minimum

\section{B. UPAH MENURUT ISLAM}

Pembayaran kepada tenaga kerja dapat dibedakan menjadi dua pengertian yaitu upah dan gaji. Dalam pengertian seharihari gaji diartikan sebagai pembayaran kepada pekerja-pekerja tetap dan tenaga profesional, seperti pegawai pemerintah, dosen, guru, manajer, dan akuntan. Pembayaran tersebut biasanya sebulan sekali. Sedangkan upah dimaksudkan sebagai pembayaran kepada pekerja-pekerja kasar yang pekerjaannya selalu berpindah-pindah, seperti misalnya pertanian, tukang kayu, tukan batu, dan buruh kasar. $^{2}$

Di dalam teori ekonomi upah diartikan sebagai pembayaran ke atas jasa- jasa fisik maupun mental yang disediakan oleh tenaga kerja kepada para pengusaha. Dengan demikian dalam teori ekonomi tidak dibedakan antara pembayaran kepada pegawai tetap dengan pembayaran kepada pekerja kasar atau tidak tetap. Di dalam teori ekonomi kedua jenis pendapatan pekerja tersebut dinamakan upah. ${ }^{3}$

Di dalam jangka panjang upah pekerja akan mempunyai kemampuan yang semakin sedikit di dalam membeli barangbarang dan jasa yang dibutuhkannya. Keadaan seperti itu timbul akibat dari kenaikan harga-harga barang dan jasa tersebut, yang selalu berlaku dari waktu ke waktu. Adanya kenaikan harga-harga akan menurunkan daya beli dari sejumlah pendapatan.di dalam jangka panjang kecenderungan yang selalu berlaku adalah keadaan dimana harga-harga barang maupun upah terus menerus mengalami kenaikan. Tetapi kenaikan tersebut tidaklah serentak dan juga tingkat kenaikannya berbeda. Walau bagaimanapun hal ini tidak menimbulkan kesulitan untuk mengetahui sampai dimana kenaikan pendapatan merupakan suatu gambaran dari kenaikan kesejahteraan yang dinikmati oleh para pekerja. Untuk tujuan tersebut ahli ekonomi membuat perbedaan diantara dua pengertian upah: Upah uang dan upah riil. Upah uang adalah jumlah uang yang diterima para pekerja dari para pengusaha

\footnotetext{
${ }^{2}$ Sukirno, S, Mikro Ekonomi Teori Pengantar. (Jakarta: Rajawali Pers, 2012), h. 350
}

${ }^{3}$ Sukirno, S, Mikro Ekonomi Teori ..., h. 351 
\begin{tabular}{r|l} 
Ayu Yuningsih & 280
\end{tabular}

sebagai pembayaran atas tenaga mental atau fisik para pekerja yang digunakan dalam proses produksi. Sedangkan upah riil adalah tingkat upah pekerja yang diukur dari sudut kemampuan upah tersebut membeli barang-barang dan jasajasa yang diperlukan untuk memenuhi kebutuhan para pekerja. ${ }^{4}$

Upah yang diterima tenaga kerja terutama tergantun kepada produktivitas dari tenaga kerja tersebut. Data mengenai kenaikan upah di berbagai negara, terutama negara-negara maju, menunjukkan bahwa kenaikan upah pekerja memiliki hubugan yang erat dengan kenaikan produktivitas mereka.

Produktivitas dapat didefinisikan sebagai produksi yang diciptakan oleh seorang pekerja pada suatu waktu terentu. Kenaikan produktivitas disebabkan oleh beberapa faktor, antara lain adalah (1) Kemajuan teknologi memproduksi, (2) Pertambahan kepandaian dan keterampilan tenaga kerja, dan (3) Perbaikan dalam organisasi perusahaan dan masyarakat. ${ }^{5}$

Seperti juga pasar barag, pasar tenaga kerja dapat dibedakan dalam beberpa jenis. Bentuk-bentuk pasar tenaga kerja yang terpenting adalah:
1. Persaingan Sempurna dalam Pasar Tenaga Kerja

Persaingan sempurna dalam pasar tenaga kerja berarti di dalam pasar terdapat banyak perusahaan yang memerlukan tenaga kerja, dan tenaga kerja yang ada dalam pasar tidak menyatukan diri dalam serikat-serikat buruh yang akan bertindak sebagai wakil mereka. Dalam pasar tenaga kerja seperti ini sifat-sifat permintaan dan penawaran tenaga kerja tidak berbeda dengan sifat-sifat permintaan dan penawaran di pasar barang. Semakin tinggi upah maka semakin banyak tenaga kerja yang bersedia menawarkan tenaganya.

\section{Pasar Tenaga Kerja Monopsoni}

Monopsoni berarti hanya terdapat satu pembeli di pasar sedangkan penjual jumlahnya banyak. Pasar tenaga kerja seperti ini bersifat monopoli di pihak perusahaan. Dengan demikian pasar tenaga kerja yang bersifat monopsoni di dalamnya hanya terdapat satu perusahaan yang akan menggunakan tenaga kerja yang ditawarkan. Pasar tenaga kerja seperti ini terwujud apabila di suatu tempat/daerah tertentu terdapat suatu firma yang sangat besar, dan ia satu-satunya perusahaan modern di tempat tersebut.

\footnotetext{
${ }^{4}$ Sukirno, S, Mikro Ekonomi Teori..., h. 351

${ }^{5}$ Sukirno, S, Mikro Ekonomi Teori..., h. 353- 


\section{Pasar Tenaga Kerja Monopoli Bilateral}

Pasar tenaga kerja monopili bilateral yaitu di dalam pasar tenaga kerja bersatu dalam serikat buruh, dan di dalam pasar tenaga kerja hanya terdapat satu perusahaan saja yang menggunakan tenaga kerja. Di dalam pasar tenaga kerja monopili bilateral ini terdapat pebedaan yang nyata di antara upah yang ditentukan oleh perusahaan dan jumlah upah yag ditentukan oleh serikat buruh.

Dari penjelasan di atas dapat disimpulkan bahwa memang tidak ada mekanisme yang tetap dalam menentukan tingkat upah bagi kaum buruh. Hal ini yang sering kai menimbulkan konflik antara buruh dan pengusaha. Upah dan gaji sudah menjadi gambaan umum dalam berbagai masyarakat di mana saja yang hubungan - hubungan kerja ditentukan dan diatur atau dikendalikan oleh golongan pengusaha dan pihak yang mempekerjakan buruh.

Selain itu upah dapat kita pandang dari dua segi, yaitu moneter dan yang bukan moneter, jumlah uang yang diterima seorang pekerja selama jangka waktu tertentu, katakanlah sebulan, seminggu, sehari, mengacu pada upah nominal tenaga kerja. Upah sesungguhnya dari seorang buruh tergantung dari berbagai faktor. Seperti jumlah upah berupa uang, daya beli uang, yang boleh dikatakan terdiri dari jumlah kebutuhan hidup yang sebenarnya diterima oleh seorang pekerja karena kerjanya. Pekerja kaya atau miskin, diberi imbalan, baik atau buruk, sebanding dengan harga nyata, bukan harga nominal atas jerih payahnya. ${ }^{6}$

Upah menurut teori "Produk Marjinal" upah ditentukan oleh keseimbangan antara kekuatan permintaan dan persediaan. Dengan mengasumsikan penyediaan tenaga kerja dalam jangka suatu yang panjang dan konstan, maka permintaan akan buruh dalam satu kerangka masyarakat kapitalis, datang dari majikan yang memperkerkjakan buruh dan faktor produksi lainya untuk membuat keuntungan dari kegiatan usahanya. Selama hasil bersih tenaga kerja lebih besar dari tarif upah itu.majikan akan semakin memperkerjakan tenaga kerja tambahan pada batas dimana biaya memperkerjakan semakin banyak satuan tenaga kerja. Tentu saja ia akan berhenti memperkerjakan tenaga kerja tambahan pada batas dimana biaya memperkerjakan buruh sama dengan pada tambahan yang dilakukan pada nilai hasil bersih. Masingmasing majiklan, seperti halnya masingmasing konsumen, memberi upah buruh yang akan bernilai sama dengan hasil kerja marjinal dengan tarif upah yang berlaku.

${ }^{6}$ Afandia,http://aafandia.wordpress.com/2009/05 /20/upah-minimum-regional-dalam-perspektif-islam/ , diakses pada 12 Mei 2018 
Hal itu merupakan permintaan semua majikan yang terjadi dalam keseluruhan hubungan dengan persediaan tertentu yang menentukan produk marjinal tenaga kerja secara keseluruhan dan tarif upah di pasaran. $^{7}$

Menurut Profesor Marsal ”Ingatalah bahwa seoarang yang memperkerjakan seribu orang lain, seolah-laha merupakan suatu gabungan yang ketat dari seribu unit diakalangan pemnbeli di pasaran tenaga kerja".disebabkan oleh kelemahan mereka dalam perundingan, maka para pekerja dibawah kapitalisme mungkin mendapat upah yang jauh lebih rendah dari produk marjinal mereka"8

Ajaran Islam yang direpresentasikan dengan aktivitas kesalehan sosial Rasulullah Shallallahu 'alaihi wa sallam yang dengan tegas mendeklarasikan sikap antiperbudakan untuk membangun tata kehidupan masyarakat yang toleran dan berkeadilan. Islam tidak mentolerir sistem perbudakan dengan alasan apa pun. Terlebih lagi adanya praktik jual-beli pekerja dan pengabaian hak-haknya yang sangat tidak menghargai nilai kemanusiaan.

Penghapusan perbudakan menyiratkan pesan bahwa pada hakikatnya

\footnotetext{
${ }^{7}$ Afandia,http://aafandia.wordpress.com/2009/05 /20/upah-minimum-regional-dalam-perspektif-islam/ , diakses pada 12 Mei 2018

${ }^{8}$ Manan, M. A, Teori dan Praktek Ekonomi Islam, (Yogyakarta: PT Dana Bhakti Wakaf, 1997)
}

manusia ialah makhluk merdeka dan berhak menentukan kehidupannya sendiri tanpa kendali orang lain. Penghormatan atas independensi manusia, baik sebagai pekerja maupun berpredikat apapun, menunjukkan bahwa ajaran Islam mengutuk keras praktik jual-beli tenaga kerja.

Upah atau gaji adalah hak pemenuhan ekonomi bagi pekerja yang menjadi kewajiban dan tidak boleh diabaikan oleh para majikan atau pihak yang mempekerjakan. Sebegitu pentingnya masalah upah pekerja ini, Islam memberi pedoman kepada para pihak yang mempekerjakan orang lain bahwa prinsip pemberian upah harus mencakup dua hal, yaitu adil dan mencukupi.

Adapun landasan upah dalam dalam Islam antara lain sebagai berikut:

1. Upah seorang buruh harus dibayarkan kepadanya sebelum keringat dibadanya kering. Hal ini sesuai dengan hadist Rasulullah saw. yang diriwayatkan oleh Ibnu Majah, yaitu sebagai berikut: Artinya: "Dari Ibnu U mar Ra bahwa Rasulullah Saw bersabda: "Berikanlah kepada pekerja upahnya sebelum mengering keringatnya."

Maksud dari hadist ini adalah bersegera menunaikan hak pekerja setelah selesai pekerjaannya, karena menunda pembayaran gaji pegawai bagi majikan yang mampu adalah kezaliman. (Syafei, 
2001) Seorang pekerja berhak menerima upahnya ketika sudah mengerjakan tugas-tugasnya, maka jika terjadi penunggakan gaji pekerja, hal tersebut selain melanggar kontrak kerja juga bertentangan dengan prinsip keadilan dalam Islam. Selain ketepatan pengupahan, keadilan juga dilihat dari proporsionalnya tingkat pekerjaan dengan jumlah upah yang diterimanya.

2. Rasulullah Shallallahu 'alaihi wa sallam mempertegas pentingnya kelayakan upah dalam sebuah hadis: "Mereka (para budak dan pelayanmu) adalah saudaramu, Allah menempatkan mereka di bawah asuhanmu, sehingga barangsiapa mempunyai saudara di bawah asuhannya maka harus diberinya makan seperti apa yang dimakannya (sendiri) dan memberi pakaian seperti apa yang dipakainya (sendiri), dan tidak membebankan pada mereka tugas yang sangat berat, dan jika kamu membebankannya dengan tugas seperti itu, maka hendaklah membantu mereka (mengerjakannya)." (HR. Muslim).

3. Dari Ibnu Majah Nabi SAW bersabda "kewajiban para majikan hanya menerima pekerjaan yang sudah dilakukan oleh para karyawanya, janganlah memperkerjakan mereka sedemikian rupa sehingga berakibat buruk bagi kesehatannya".
4. Penghasilan terbaik ialah penghasilan seorang pekerja dengan syarat ia melakukan pekerjaanya dengan hati-hati dan ia hormat pada majikanya.

\section{FAKTOR-FAKTOR YANG MENIMBULKAN PERBEDAAN UPAH}

Faktor - Faktor yang menimbulkan perbedaan upah adalah sebagai berikut: ${ }^{9}$

1. Permintaan dan Penawaran Tenaga Kerja

Permintaan dan penawaran tenaga kerja dalam suatu jenis pekerjaan memiliki pengaruh yang besar dalam menentukan upah di suatu jenis pekerjaan. Di dalam suatu pekerjaan dimana terdapat penawaran tenaga kerja yang cukup besar tetapi tidak banyak permintaannya, upah cenderung rendah. Sebaliknya di dalam suatu pekerjaan dimana terdapat suatu penawaran tenaga kerja yang tebatas tetapi permintaannya sangat besar, maka upah cenderung tinggi.

2. Perbedaan Corak Pekerjaan

Kegiatan ekonomi meliputi berbagai jenis pekerjaan. Ada diantara pekerjaan tersebut merupakan pekerjaan yang ringan dan sangat mudah dikerjakan. Tetapi ada pula pekerjaan yang harus dikerjakan dengan mengeluarkan tenaga fisik yang besar dan ada pula pekerjaan yang harus dilakukan dalam lingkungan 
yang tidak menyenangkan. Untuk tingkat pekerjaan yang memerlukan tenaga fisik yang besar dan lingkungan yang kurang menyeangkan tentuya menginginkan upah yang lebih tinggi.

3. Perbedaan Kemampuan, keahlian, dan pendidikan

Kemampuan, keterampilan dan keahlian para pekerja di dalam suatu jenis pekerjaan berbeda-beda. Secara lahiriah segolongan pekerja mempunyai kepandaian, ketekunan dan ketelitian yang lebih baik dibanding yang lain. Sifat tersebut menyebabkan mereka mempunyai produktivitas yang lebih tinggi. Maka para pengusaha biasanya tidak segan-segan untuk memberikan upah yang lebih tinggi kepada pekerja yang seperti itu.

Dalam perekonomian yang semakin maju kegiatan-kegiatan ekonomi semakin memerlukan tenaga terdidik. Manajer profesional, tenaga teknik, tenaga akuntan, dan berbagai tenaga profesonal lainnya akan selalu diperlukan untuk memimpin perusahaan modern dan menjalankan kegiatan memproduksi secara modern. Biasanya semakin rumit pekerjaan yang diperlukan, maka semakin lama masa pendidikan dari tenaga ahli yang diperlukan. Maka pendidikan yang panjang tersebut menyebabkan tidak banyak tenaga kerja yang dapat mencapai taraf pendidikan yang tinggi. Kekurangan penawaran seperti itu menyebabkan upah yang diperoleh tenaga terdidik lebih tnggi daripada parapekerja yan lebih renda pendidikannya. Di samping itu, tenaga kerja yang lebih tinggi tinkat pendidikannya mempertnggi keampuan kerja dan selanjutnya kemampuan kemampuan kerja menaikkan prdkivitasnya.

4. Pertimbangan bukan keuangan

Daya tarik suatu pekerjaan bukan saja tergantung pada besarnya upah yang ditawarkan. Faktor-Faktor bukan keuangan mempunyai peranan yang cukup penting pada waktu seseorang memilih pekerjaan. Seseorang sering sekali menerima upah yang lebih rendah apabila beberapa pertimbangan bukan keuangan sesuai dengan keinginannya. Sebaliknya, apabila faktor-faktor bukan keuangan banyak yang tidak sesuai dengan keinina seorang pekerja, ia akan menuntut upah yang lebih tinggi sebelum ia bersedia menerima pekerjaan yang ditawarkan.

5. Mobilitas Tenaga Kerja

Dalam konteks mobilitas tenaga kerja ini berarti bahwa jika dalam pasar tenaga kerja terjadi perbedaan upah, maka tenaga kerja akan mengalir ke pasar tenaga kerja yang upahnya lebih tinggi. Perpindahan tersebut akan terus 
berlangsung sehingga tidak terdapat lag perbedaan upah. Pemisalan ini sangat berbeda dengan kenyataan yang terlaksana dalam prakteknya. Uapah dari suatu pekerjaan di berbagai wilayah dan bahkan di dalam suatu wilayah tidak selalu sama. Salah satu faktor yang menimbulkan perbedaan tersebut adalah ketidaksempurnaan mobilitas tenaga kerja.

\section{Faktor Geografis}

Faktor geografis merupakan salah satu faktor yang menyebabkan timbulnya ketidaksempurnaan mobilitas tenaga kerja. Adakalanya di tempat-tempat tertentu terdapat masalah kekurangan buruh walaupun tingkat upah lebih tinggi, sedangkan di tempat lain terdapat penganggurandan tingkat upahnya relatif rendah. Dalam keadaan seperti itu adalah wajar apabila para penganggur tersebut pindah ke tempat dimana kekurangan tenaga kerja. Dalam kenyataannya perpindahan tersebut belum tentu berlaku. Keengganan untuk meninggalkan kampung halamandan sanak saudara sering sekali mencegah orang untuk pindah ke tempat lain, walaupun upah dan kesempatan untuk maju lebih besar.

\section{Faktor Institusional}

Ketidaksempurnaan dalam mobilitas tenaga kerja disebabkan juga oleh aktorfaktor nstitusional. Dalam pekerjaan- pekerjaan tertentuterdapat organisasiorganisasi profesional yang berusaha membatasi kemasukan tenaga prfesional yang baru. Tujuannya adalah untuk menjamin supaya pendapata mereka tetap berada pada tingkat yang tinggi. Di Indonesia faktor institusional tidaklah merupakan faktor yang penting yang dapat menghambat mobilitas tenaga kerja.

Lebih jauh lagi, Syarif Arifin dalam sebuah artikel tentang Buruh dan Upah memaparkan bahwa faktor yang menyebabkan rendahnya tingkat upah buruh di Indonesia adalah sebagai berikut: ${ }^{10}$

1. upah biasanya mengikuti aturan hukum pasar: permintaan dan penawaran terhadap tenaga kerja. Jumlah calon penjual tenaga kerja (termasuk angka pengangguran) yang melimpah, melemahkan posisi tawar buruh terhadap penyewa atau pembeli tenaga kerja (pengusaha). Belum lagi ditambah denga banyak jumlah buruh yang diPHK. Akibatnya, upah sebagai harga tenaga kerja mengalami kemerosotan;

2. penentu upah juga didasar pada kebijakan pemerintah. Selama orde baru, pemerintah menetapkan tingkat upah yang rendah bagi buruh melalui pemberlakuan upah minimum yang

10 Arifin, S, Buruh dan Upah. Jakarta: http://hidupburuh.blogspot.co.id/2013/08/buruh-danupah.html, 2013, diakses pada Maret 2018. 
berbeda-beda di setiap daerah. Survei dan penelitian yang dilakukan pihak pemerintah hanya sekedar untuk membenarkan ukuran-ukuran upah yang rendah. Tak ada rencana kebijakan pemerintah untuk menyejahterakan buruh;

3. masih terjadi diskriminasi rasial terhadap buruh Indonesia. tampak pikiran rasialis dalam memandang buruh Indonesia ketika dibandingkan buruh dari luar negeri yang bekerja di Indonesia seperti dari Amerika Serikat, Jepang dan Korea Selatan, bahkan India. Sejumlah perusahaan yang mempekerjakan buruh asing ini memberlakukan upah yang tinggi dan fasilitas yang memadai, sementara buruh-buruh Indonesia diberlakukan upah yang rendah;

4. upah buruh juga menghadapi faktor inflasi. Ketika harga barang dan jasa melambung, upah buruh justru merosot secara riil.

\section{MEKANISME PENETAPAN UPAH MINIMUM}

Dalam peraturan Menteri Tenaga Kerja dan Transmigrasi Nomor 7 Tahun 2013 tentang Upah Minimum, menjelaskan pengertian uapah minimum sebagai berikut:

1. Upah Minimum adalah upah bulanan terendah yang terdiri atas upah pokok termasuk tunjangan tetap yang ditetapkan oleh gubernur sebagai jaring pengaman.

2. Upah Minimum Provinsi yang selanjutnya disingkat UMP adalah Upah Minimum yang berlaku untuk seluruh kabupaten/kota di satu provinsi.

3. Upah Minimum Kabupaten/Kota yang selanjutnya disingkat UMK adalah Upah Minimum yang berlaku di wilayah kabupaten/kota.

4. Minimum Sektoral Provinsi yang selanjutnya disingkat UMSP adalah Upah Minimum yang berlaku secara sektoral di satu provinsi.

5. Upah Minimum Sektoral Kabupaten/Kota yang selanjutnya disingkat UMSK adalah Upah Minimum yang berlaku secara sektoral di wilayah kabupaten/kota.

Berdasarkan

Menteri

Ketenagakerjaan dan Transmigrasi Republik Indonesia Nomor 7 Tahun 2003 Tentang Upah Minimum peraturan tersebut penetapan upah minimum didasarkan pada Kebutuhan Hidup Layak (KHL) selanjutnya disebut KHL dengan memperhatikan produktivitas dan pertumbuhan ekonomi, upah minimum diarahkan pada pencapaian KHL. Untuk pencapaian KHL dapat dihitung dari perbandingan besarnya Upah Minimum terhadap nilai KHL pada periode yang sama. Untuk pencapaian KHL tersebut gubernur menetapkan tahapan pencapaian 
KHL dalam bentuk peta jalan pencapaian KHL bagai perusahaan Industri Padat Karya Tertentu dan bagi perusahaan lainnya dengan mempertimbangkan kondisi kemampuan dunia usaha. Apabila kondisi perekonomian pada tahun tertentu pencapaian KHL tidak dapat terpenuhi, maka gubernur dapat melakukan penyesuaian tahapan pencapaian KHL.

Penetapan Upah Minimum dilakukan dengan menggunakan formula perhitungan Upah Minimum, yaitu Upah Minimum Tahun berjalan ditambah dengan hasil perkalian antara Upah Minimum tahun berjalan dengan penjumlahan tingkat inflasi nasional tahun berjalan dan tingkat pertumbuhan produk domestik bruto tahun berjalan. Dalam penetapan Upah Minimum KHL terdapat pada Upah Minimum Tahun berjalan.

Dalam penetapan upah minimum setiap tahun terdapat penyesuaian nilai KHL. Penyesuaian nilai KHL secara langsung terkoreksi melalui perkalian antara Upah Minimum tahun berjalan dengan tingkat inflasi nasional tahun berjalan.

Dalam pelaksanaan penetapan Upah Minimum yang tertuang pada Bab IV pasal 15 Peraturan Menteri Tenaga Kerja dan Transmigrasi Nomor 7 Tahun 2013 tertulis jelas bahwa pengusaha dilarang membayar upah lebih rendah dari upah minimum yang telah ditetapkan selain itu upah minimum hanya berlaku bagi pekerja/buruh yang mempunyai masa kerja kurang dari 1 tahun.

E. Pandangan Ekonomi Islam Terhadap Upah Minimum yang tertuang dalam Peraturan Menteri Tenaga Kerja dan Transmigrasi Nomor 7 Tahun 2013

Titik sentral etika Islam adalah menentkan kebebasan manusia untuk bertindak dan bertangungjawab karena kepercayaannya terhadap Tuhan. Jika manusia diberi kebebasan kehendak yang mutlak, maka kemahakuasaan Tuhan tercemar. Sebaliknya, jika kepercayaan secara eksklusif didasarkan pada kemahakuasaan Tuhan, maka tanggungjawab manusia atas tindakannya, atau dasar eskatologis agama menjadi tak bermakna. Dalam skema etik Islam, manusia adalah pusat ciptaan Tuhan. Manusia merupakan wakil Tuhan (khalifatullah) di bumi: “..... Dan Dialah yang menjadikan kamu penguasa-penguasa di bumi...." (QS. 6:165). Karena itu seluruh tujuan hidup manusia adalah untuk mewujudkan kebajikan kekhalifahannya sebagai pelaku bebas karena dibekali kehendak bebas, mampu memilih atara kehendak baik dan kehendak jahat, antara yang bear dan salah. Berdasarkan kebebasan ini, manusia dapat mewujudkan kebajikan teomorfik dari keberadaannya sebagai wakil Tuhan di muka bumi, ataupun menolak kedudukan yang agung ini dengan melakukan pilihan yang salah. 
\begin{tabular}{r|c} 
Ayu Yuningsih & 288
\end{tabular}

Dengan kata lain, manusia akan mempertanggungjawabkan pilihan-pilihan yang diambilnya dalam kapasitasnya sebagai individu. ${ }^{11}$

Inti ajaran Islam di bidang ekonomi adalah "maslahah dan adl". Maslahah terkait dengan nilai absolut keberadaan barang, jasa, atau action (termasuk kebijakan ekonomi) dimana kesemuanya harus memenuhi kriteria-kriteria yang mengarah pada perwujudan syariah (maqashid al-syariah) yaitu perlindungan agama, jiwa akal, harta dan keturunan. Manusia tidak berhak atas bagian yang tidak diberikan Tuhan kepadanya, Tuhan memberikan pada setiap orang haknya oleh karena itu jangan menggangu apa yang dimiliki orang lain. Sementara $a d l$ terkait dengan interaksi relatif antara satu hal dengan hal lain, individu yang satu dengan individu yang lain, atau masyarakat tertentu dengan masyarakat yang lain. (Susanto, 2008)

Untuk mewujudkan kedua norma utama tersebut, diperlukan beberapa institusi yaitu mencakup anatara lain: pertama, bentuk kepemilikan yang multijenis, disatu sisi mengakui dan melindungi kepemilikan individu, tetapi disisi lain juga menekankan penghormatan atas kepemilikan bersama dalam konteks

11 Naqvi, Menggagas Ilmu Ekonomi Islam. (Yogyakarta: Pustaka Pelajar, 2003), h. 50 masyarakat atau negara, kedua, insentif dunia plus akhirat sebagai motivasi untuk melakukan kegiatan ekonomi, ketiga, kebebasan berusaha, keempat, pasar sebagai mekanisme pertukaran ekonomi, kelima, peran pemerintah untuk menjaga pasar sedemikian rupa sehingga kemaslahatan dan keadilan dapat terwujud.

Solusi terhadap problem Upah Minimum ini tentu saja harus terus diupayakan dan diharapkan mampu membangun kondisi seideal mungkin. Untuk tujuan itu, setidaknya ada dua kondisi mendesak yang harus diwujudkan, yaitu :

1. Kondisi normal (persaingan sempurna) yang mampu menyetarakan posisi buruh-pengusaha sehingga penentuan besarnya upah disepakati oleh kedua pihak yang besarnya ditentukan oleh besaran peran serta kerja pihak buruh terhadap jalannya usaha perusahaan yang bersangkutan. Kondisi seperti ini bisa terwujud jika kualitas SDM buruh memadai sesuai dengan kebutuhan, dan besarnya pasar tenaga kerja seimbang. Kondisi seperti ini akan mampu mewujudkan "akad ijarah" (perjanjian kerja) yang dalam pandangan syariat Islam yang didefinisikan secara ringkas sebagai "'Aqdun 'ala al manfa'ati bi "iwadhin" (Aqad atas suatu manfaat dengan imbalan/ upah). 
2. Mewujudkan kondisi ideal ketika seluruh rakyat (bukan hanya kaum buruh) memiliki pendapatan lain untuk memenuhi kebutuhan dasar minimal (hajat asasiyah) bagi kehidupannya. Perwujudan kondisi ini, dalam pandangan syariat Islam menjadi tanggung jawab utama negara. Dalam politik ekonomi Islam, pemerintah bertanggung jawab untuk memenuhi kebutuhan pokok (primer) rakyat dan mempermudah kesempatan untuk kebutuhan tambahan (sekunder ataupun tersier)

Kontak kerja antara pengusaha dan pekerja adalah kontrak kerja sama yang harusnya saling menguntungkan. Pengusaha diuntungkan karena memeroleh jasa dari pekerja untuk melaksanakan pekerjaan tertentu yang dibutuhkan pengusaha. Sebaliknya, pekerja diuntungkan karena memperoleh penghasilan dari imbalan yang diberikan pengusaha karena memberikan jasa kepada pengusaha. Karena itulah, hubungan ketenagakerjaan di dalam pandangan Islam adalah hubungan kemitraaan yang harusnya saling menguntungkan. Tidak boleh satu pihak menzalimi dan merasa dizalimi oleh pihak lainnya.

Agar hubungan kemitraan tersebut dapat berjalan dengan baik dan semua pihak yang terlibat saling diuntungkan, maka Islam mengaturnya secara jelas dan terperinci dengan hukum-hukum yang berhubungan dengan ijaratul ajir (kontrak kerja). Pengaturan tersebut mencakup penetapan ketentuan-ketentuan Islam dalam kontrak kerja antara pengusaha dan pekerja; penetapan ketentuan yang mengatur penyelesaian perselisihan yang terjadi antara pengusaha dan pekerja. Termasuk ketentuan yang mengatur bagaimana cara mengatasi tindakan kezaliman yang dilakukan salah satu pihak (pengusaha dan pekerja) terhadap pihak lainnya.

Pola dalam suatu masyaraka Islam, upah yang layak bukanlah suatu konsesi, tetapi suatu hak asasi, yang dapat dipaksakan oleh seluruh kekuatan negara. Bila reorientasi sikap negara telah dilaksanakan, maka penetapan upah dan perumusan produktifitas sesuangguhnya hanya merupakan penyesuaian yang tepat. Sesungguhnya Islam menghendaki pertumbuhan masyarakat yang berimbang, untuk itu kompromi antara buruh dan majikan dianggap sebagai prasyarat yang hakiki.

Dalam Peraturan Menteri Tenaga Kerja dan Transmigrasi Nomor 7 Tahun 2013, telah diatur secara rinci mengenai penetapan Uapah Minimum. Dalam penetapannya pemerintah juga melibatkan kesepakatan kaum buruh. Selain itu, melalui peraturan ini pemerintah ikut mengawasi dan melindungi hak-hak buruh 
\begin{tabular}{r|l} 
Ayu Yuningsih & 290
\end{tabular}

dan pengusaha terkait dengan kerjasama dan pengupahan. Menurut hemat penulis, Peraturan Menteri Tenaga Kerja dan Transmigrasi Nomor 7 Tahun 2013 pada dasarnya sudah sesuai dengan prinsip Maslahah dan Adl. Akan tetapi memang perlu adanya pengawasan yang ketat dari pemerintah agar sistem itu dapat berjalan sebagaimana yang diharapkan.

Untuk meningkatkan Upah buruh, maka kualitas SDM / buruh harus terus ditingkatkan secara terus menerus, proses penetapan upah antara buruh drngan pengusaha harus dilakukan secara adil, dengan posisi masing-masing sebagai mitra yang seimbang.

Konsep kesepakatan dalam Islam dapat menjadi alternatif dalam proses penentuan upah, tampa harus dimunculkan istilah-istilah Islam yang membuat pihak tertentu pobia dengan istilah tersebut, akan tetapi nilai Islam dapat diimplementasikan dalam perjanjian penentuan upah yang adil dan seimbang.

Syariat memperbolehkan campur tangan pemerintah Islam untuk membatasi (menetapkan standar) upah kerja jika diperlukan dan demi pertimbangan kemaslahatan. Selain itu, juga bertujuan untuk menegakkan keadilan dan menghilangkan kezhaliman, mencegah sebab-sebab yang menjadikan pertentangan dan percekcokan, menolak mudarat yang akan terjadi pada salah satu pihak. Semua langkah itu dilakukan dengan syarat melalui pertimbangan para ahlinya dan para ahli agama yang dapat menetapkan standar upah secara adil, tanpa menganiaya para pekerja (kaum buruh) juga majikan, tanpa memihak salah satunya, sebagaimana dibolehkannya pemerintah untuk campur tangan dalam menentukan jam kerja, cuti mingguan, cuti tahunan, cuti pada waktu sakit, dan sebagainya. Campur tangan pemerintah yang dimaksud di sini misalnya yang berhubungan dengan honorarium, gaji dan tunjangan pegawai, karyawan dan buruh yang seharusnya diberikan oleh majikan sesuai dengan kondisi riil, menurut standar kelayakan umum.

\section{F. KESIMPULAN}

Proses penetapan Upah Minimum, kesepakatan upah dari pihak pengusaha dan buruh dalam kondisi normal dan dalam sudut pandang keadilan ekonomi, seharusnya nilai upah sebanding dengan besarnya peran jasa buruh dalam mewujudkan hasil usaha dari perusahaan yang bersangkutan. Peraturan Menteri Tenaga Kerja dan Transmigrasi Nomor 7 tahun 2013 pada dasarnya sudah sesuai dengan prinsip Maslahah dan Adl yang menjadi inti dari agama Islam. Dimana kesemuanya harus memenuhi kriteriakriteria yang mengarah pada perwujudan syariah (maqashid al-syariah) yaitu perlindungan agama, jiwa akal, harta dan keturunan. Manusia tidak berhak atas 
bagian yang tidak diberikan Tuhan kepadanya, Tuhan memberikan pada setiap orang haknya oleh karena itu jangan menggangu apa yang dimiliki orang lain. Sementara $a d l$ terkait dengan interaksi relatif antara satu hal dengan hal lain, individu yang satu dengan individu yang lain, atau masyarakat tertentu dengan masyarakat yang lain.

\section{DAFTAR PUSTAKA}

Arifin, S. 2013. Buruh dan Upah. Jakarta: http://hidupburuh.blogspot.co.id/2013/0 8/buruh-dan-upah.html, diakses pada Maret 2018.

Afandia. (2009, 05 20). Retrieved 05 12, 2018 , http://aafandia.wordpress.com/2009/05/ 20/upah-minimum-regional-dalamperspektif-islam/

Manan, M. A. 1997. Teori dan Praktek Ekonomi Islam. Yogyakarta: PT Dana Bhakti Wakaf.

Naqvi. 2003. Menggagas Ilmu Ekonomi Islam. Yogyakarta: Pustaka Pelajar.

Sukirno, S. 2012. Mikro Ekonomi Teori Pengantar. Jakarta: Rajawali Pers.

Susanto, A. A. 2008. Praktek Ekonomi Islam di Indonesia dan Implikasinya Terhadap Perekonomian. Jurnal Ekonomi Syariah Muamalah, 5.

Syafei, R. 2001. Fiqh Muamalah. Bandung: Pustaka Setia.

Peraturan Kementerian Tenaga Kerja dan Transmigrasi Nomor 7 Tahun 2013 